2014-09-23

\title{
Creditable behaviour? The intra-firm management of trade credit
}

\section{Boden, $\mathrm{R}$}

http://hdl.handle.net/10026.1/11328

10.1108/qram-08-2012-0032

Qualitative Research in Accounting \&amp; Management

Emerald

All content in PEARL is protected by copyright law. Author manuscripts are made available in accordance with publisher policies. Please cite only the published version using the details provided on the item record or document. In the absence of an open licence (e.g. Creative Commons), permissions for further reuse of content should be sought from the publisher or author. 


\section{Qualitative Research in Accounting \& Management}

Creditable behaviour? The intra-firm management of trade credit

Rebecca Boden Salima Yassia Paul

\section{Article information:}

To cite this document:

Rebecca Boden Salima Yassia Paul , (2014),"Creditable behaviour? The intra-firm management of trade credit", Qualitative Research in Accounting \& Management, Vol. 11 Iss 3 pp. 260 - 275

Permanent link to this document:

http://dx.doi.org/10.1108/QRAM-08-2012-0032

Downloaded on: 01 November 2014, At: 10:14 (PT)

References: this document contains references to 17 other documents.

To copy this document: permissions@emeraldinsight.com

The fulltext of this document has been downloaded 18 times since 2014*

\section{Users who downloaded this article also downloaded:}

Lawrence Peter Shao, Alan T. Shao, Iftekhar Hasan, (1997),"INTERNATIONAL CREDIT MANAGEMENT POLICIES OF U.S. SUBSIDIARIES", Managerial Finance, Vol. 23 Iss 4 pp. 19-33

Peihwang Wei, Susan M.L. Zee, (1997),"TRADE CREDIT AS QUALITY SIGNAL: AN INTERNATIONAL COMPARISON", Managerial Finance, Vol. 23 Iss 4 pp. 63-72

(1999),"Credit where credit is due", Education + Training, Vol. 41 Iss 2 pp. -

Access to this document was granted through an Emerald subscription provided by

Token:J ournalAuthor:37819021-5781-4C0E-8B90-BDADF19A3289:

\section{For Authors}

If you would like to write for this, or any other Emerald publication, then please use our Emerald for Authors service information about how to choose which publication to write for and submission guidelines are available for all. Please visit www. emeraldinsight.com/ authors for more information.

\section{About Emerald www.emeraldinsight.com}

Emerald is a global publisher linking research and practice to the benefit of society. The company manages a portfolio of more than 290 journals and over 2,350 books and book series volumes, as well as providing an extensive range of online products and additional customer resources and services.

Emerald is both COUNTER 4 and TRANSFER compliant. The organization is a partner of the Committee on Publication Ethics (COPE) and also works with Portico and the LOCKSS initiative for digital archive preservation. 
QRAM 11,3

260

Received 22 August 2012 Revised 19 July 2013 Accepted 4 September 2013

\title{
Creditable behaviour? The intra- firm management of trade credit
}

Rebecca Boden

Business School, University of Roehampton, London, UK, and

Salima Yassia Paul

School of Management, University of Plymouth, Plymouth, UK

\begin{abstract}
Purpose - This paper aims to explore the reasons for the apparent failure of many UK firms to achieve the competitive advantages indicated in largely positivist literature through the management of their trade credit positions.

Design/methodology/approach - The paper utilises data from a set of semi-structured interviews with trade credit managers in firms and is the first substantial qualitative study of the intra-firm aspects of trade credit management in the UK. Through this approach, we explore the reasons why the theoretical promise of trade credit may or may not be realised.

Findings - The principal findings relate to the importance of three organisational attributes (skills/ awareness, communication and structural position of the activity in the firm). That is, trade credit management should be regarded as a relational activity and not merely a narrow technical function. The paper finds that there is no generic formulation of these attributes that can deliver on the promise of trade credit identified in the extant literature. Rather, individual firms must adapt themselves to suit their circumstances.

Practical implications - This paper will be of interest to and is relevant for companies, accounting professionals and policymakers. Trade credit represents a significant area of commercial risk, and the problems experienced with its effective management have previously proved somewhat intractable.

Originality/value - This paper reports on the first substantial piece of UK work to look at the actualities of how trade credit is managed within firms and what the implications of this are.
\end{abstract}

Keywords Trade credit, Information asymmetries, Customer relationships, Financing costs, Skills, Communication, Structural position

Paper type Research paper

\section{Introduction}

Current global economic difficulties provide an imperative for firms to improve working

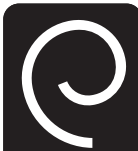
capital management - especially the appropriate management of buying and selling on credit to customers who may have a reduced capacity or willingness to pay on time. Late or non-payment can slow or fatally rupture cash-conversion cycles. Trade credit represents a significant risk; in the UK, over 80 per cent of business-to-business sales are on credit, and receivables constitute a major part of firms' total assets (Wilson and Summers, 2002).

The strategic management of firms' net credit position, defined as the balance

Qualitative Research in Accounting \& Management

Vol. 11 No. 3, 2014

pp. $260-275$

(c) Emerald Group Publishing Limited 1176-6093

DOI 10.1108/QRAM-08-2012-0032

The authors gratefully acknowledge the support of ACCA for the funding that made this work possible and the assistance afforded by Emmanouil Schizas, ACCA Senior Economic Analyst. 
well beyond cash flow control. Managed effectively, trade credit can also confer competitive advantage in terms of information and signalling, customer relationships and financing of working capital (Paul and Boden, 2011).

There is ample, normatively-determined theory of how effective trade credit management should work (Paul and Boden, 2008). However, there is also considerable disparity between theory and many firms' practices. Accordingly, consideration of how internal organisational attributes impact on the ability to manage trade credit for competitive advantage (Mian and Smith, 1992; Paul and Boden, 2008; Pike et al., 2005) forms the focus of this paper, which necessarily adopts a qualitative approach to access data on how firms work at a micro-level. We draw on data collected for a major qualitative study of UK firms' trade credit policies and practices in which we conducted 40 semi-structured interviews with credit managers/controllers from firms of varying size and sectors in 2010 and 2011 (Paul and Boden, 2012). Details of respondents are provided in Appendix 1.

In Section 2, we detail how the predominantly normative and quantitative positivist literature suggests that effective trade credit management can reduce information asymmetries, build and sustain customer relationships and reduce financing costs. These aspects are then counterpoised against three organisational attributes of firms found to be significant in our empirical study: skills and awareness of trade credit, communication and the structural position of the credit function in the firm. In Section 3, we present three contrasting pairs of firms from our empirical study, one for each of the theoretical potentialities of trade credit and analyse these in terms of their organisational attributes. This is followed by a discussion.

\section{Making credit work}

The management of trade credit can be narrowly viewed as a simple business function utilising a range of expert technical knowledge. In this form, it can even be dis-embedded from the organisation and outsourced to debt factors, payment services and credit collection agencies. Such approaches involve high degrees of specification (for instance, of credit terms or even of Information Technology (IT) payment systems) and low degrees of discretion, negotiation or even face-to-face involvement.

For such highly structured and routinised functional approaches to work well, firms need either market dominance or a vital role in the supply chain (by virtue of product or position) so that they can be relatively inflexible with regard to credit terms. Few firms are likely to enjoy such advantages, certainly with regard to all of their customers and suppliers. To gain a competitive advantage from trade credit management, most firms must have more flexible, relational approaches. Three possible advantages of such relational approaches can be identified:

(1) the mitigation of information asymmetries;

(2) the building of stronger customer relationships; and

(3) financial control.

We now discuss each of these in turn.

\section{Information and signalling}

Signalling theory suggests that trade credit data can be useful in correcting information asymmetries where suppliers are unsure whether the buyer intends to pay on time or not 


\section{QRAM 11,3}

262
(Ng et al., 1999; Paul and Boden, 2008), allowing early identification of potential problems (Smith, 1987). For example, if buyers fail to make use of an early payment discount, this indicates possible cash-flow problems. Trade credit can therefore serve as a "trip wire to alert the supplier of deterioration in the buyer's creditworthiness" (Petersen and Rajan, 1997, p. 663).

Trade credit can also signal product quality. Firms with established reputations for quality tend to extend less trade credit than those that need to prove quality (Long et al., 1993; Pike and Cheng, 2001) - "trade credit may be viewed as the strongest form of product warranty", as it gives buyers the option of not paying if they are not satisfied with the quality (Lee and Stowe, 1993, p. 286).

\section{Customer relationships}

Trade credit can provide information about customers and help to build relationships with them (Paul and Boden, 2011; Paul and Wilson, 2006; Wilson, 2008; Wilson and Summers, 2002). It is:

[...] an important strategic or competitive tool that plays a role in capturing new business, in building supplier-customer relationships, in signalling product quality, "reputation" and financial health and in price competition and price discrimination (Peel et al., 2000, p. 17).

There is a strong positive correlation between the credit period offered to customers and the strength of customer relationships as suppliers invest in those with whom they have a long-term alliance (Paul, 2010).

\section{Costs of finance}

Finally, efficient trade credit management can cut firms' costs because knowledge of customers' behaviour gained from payment patterns leads to more accurate cash flow forecasts, reducing holding requirements and therefore decreasing the cost of precautionary balances (Pike and Cheng, 2001). Schwartz (1974, p. 643) argues that "trade credit gives the buyers time to plan for the payment of unexpected purchases, enables them to forecast future cash outlays with greater certainty and simplifies their cash-flow management". Firms can benefit if bills are paid simultaneously, as this reduces transaction costs (Schwartz, 1974).

Trade credit can therefore compensate firms with weaker market positions and roles in the supply chain by improving information availability, building strong supply chains and mitigating costs. However, this begs the question of trade credit arrangements that firms have to have in place to achieve this potential. Our empirical study (Paul and Boden, 2012) identified three main organisational factors that affected firms' ability to achieve these strategic advantages: skills and awareness, communication and the structural position of the function in the firm. We now describe each of these in turn.

\section{Skills and awareness}

We found considerable heterogeneity in the skills and training of trade credit staff (Paul and Boden, 2012). Some were professionally qualified and had membership of, for example, the Institute of Credit Management; those without formal training sometimes had good skills acquired "on the job". For small business owners in particular, skills were largely self-taught and intuitive. 
Where trade credit was treated as a back-office function, staff awareness of the strategic potentiality of relational modes of working was often commensurately lower, and staff skills poorer. In contrast, in some firms, staff had acted as "champions" for trade credit, raising awareness and converting organisational behaviour and ethos. These staff were proactive in customer relationship-building and were able to work flexibly to achieve mutually beneficial outcomes.

Finally, sheer staff numbers could also be influential. In a number of firms, trade credit had been significantly outsourced; these firms often simply did not have staff physically present who could act as advocates for relational ways of working.

\section{Communication}

We found that the skills and capacities of specialist staff and their position within their firms to a significant extent determined how effectively the strategic advantages of trade credit were communicated to co-workers and customers. In turn, this had an impact on the extent to which good trade credit practices were embedded with the organisation. Because trade credit impacts on every aspect of a firm's activities, the ability to share credit information on customers to support decision-making information flows was of crucial importance. Likewise, communication between firms and their customers on credit issues was also key - some firms were energetic in their education of customers and in building good credit relationships with them.

\section{Structural position within the firm}

To manage trade credit for strategic advantage, the function must be appropriately positioned within the firm and the staff sufficiently influential such that credit management considerations are central to key decision-making (Paul and Boden, 2012). If the credit management function is a residual process following sales transactions, it cannot be influential. Similarly, reporting lines are important, as they give access to key decision-makers. Finally, the existence and implementation of formal trade credit policies and procedures, even if these allow significant discretion, act as a locus of power.

These overlapping organisational aspects are crucial to the strategic use of trade credit management in terms of mitigating information asymmetries, building customer relationships and in financing. In the following section, we present exemplars of excellent and poor practice from our empirical work that illustrate the role of these organisational attributes in each of the areas of information asymmetry, customer relationships and finance. All firms have been anonymised.

\section{Theoretical ideals and firm reality}

We now present a cross-sectional analysis, taking each of the potential advantages of trade credit posited by theory and considering how organisational attributes affect the realisation of these advantages.

\section{Rebalancing information asymmetries}

Bascule is a long-established company providing highly skilled technical consulting services to the construction sector. An employee-owned organisation in sound financial health, it has no debt-financing and has a broad customer base. As is common with the construction sector in the UK, the normal payment periods for trade debts are lengthy between 60 and 90 days. 
QRAM 11,3

264
Bascule has a well-qualified trade credit team actively involved in the firm's operations:

We always say we're a little bit like dustmen. You know, we're there, we fix something, nobody knows what we do, but if we didn't do it then it would become apparent (Credit manager, Bascule).

The large number of high-value international projects in which Bascule is engaged present serious potential financial risks, which are mitigated by the credit team having a keen awareness of their operating environment. The credit manager evidenced a keen understanding of the complexities and nuanced nature of the business, and saw himself as "translating" between technical colleagues and the commercial departments. Hence, part of the skill was in adopting a flexible and agile approach to suit the local environment.

Skills, therefore, can be construed both in terms of technical knowledge and the ability of staff to interpolate themselves into the organisation in a useful way:

We know the good and the bad, we know how to deal with them [...] so yes, I mean if you look at the credit management team [...] tied up within that is quite a lot of knowledge [...] so if we're going to work with a particular company, and we haven't been working with them before I can ask the team and each person will have [an answer to the question] "what are these guys like?" [...] Within that team there is a lot of intelligence as to who are the goodies and who are the baddies $[\ldots]$ we are seen as people who know our stuff $[\ldots]$ generally we are well regarded within the company in terms of the job we do (Credit manager, Bascule).

The fact that Bascule is employee-owned made a considerable difference to the credit team's ability to deploy its knowledge. Bascule is non-hierarchical and employees share a sense of responsibility for commercial success, which translated into profit-shares:

Because it's employee-owned and because everybody has, in theory, the best interests of the firm at heart, that if you say to somebody, "Look, there is a big risk that there is going to be a problem" [...] it affects people's bonus, but also it affects people's reputation because nobody wants to be seen as the person who's lost the money (Credit manager, Bascule).

The credit function supported the work of the firm rather than being a part of its primary offer to customers; Bascule did not use trade credit to win customers. Despite this, the credit team was, nonetheless, as the manager put it:

$[\ldots]$ very much part of the process [...] We have monthly meetings with senior managers at each of the parts of the company, so we will go and discuss key problems once a month [...] we don't like to hog the limelight. We liked to get the credit for doing a quiet job in the background (Credit manager, Bascule).

For instance, the credit managers are formally involved at initial contract negotiation stages and in undertaking risk assessments, etc. In doing this, they deploy their knowledge of the sector and players within it. Most of the influence that could be wielded by the credit function was derived not from any formal structural position, but by working alongside and with colleagues with other responsibilities. The credit manager described how the team had developed "a partnership approach with the [Bascule] sales people because ultimately that's mutually beneficial".

Bascule's longstanding customer relationships allowed the credit team to develop enhanced knowledge of them. The extended nature of serial subcontracting meant that it was necessary to have a nuanced knowledge of the whole supply chain network. The 
credit team had this and, because of their skills and position with the firm, were able to communicate their knowledge to colleagues:

To give you an example, one I saw yesterday, I put an email together to explain concerns and got an email back this morning to say "This is understood" [...] So, if you think about it, we almost (sic) providing an internal consultancy service because we are providing advice to people about potential pitfalls but we are not saying to them "do this, don't do this" because you've got to remember these guys are very senior. Credit control here is more about relationship building (Credit manager, Bascule).

Bascule also purchased goods and services - although mostly this was items like travel, etc. The firm prided itself on being good payers because it was keen to sustain a reputation for being good to do business with. The credit manager felt that by giving suppliers information about itself, it would secure better deals.

In contrast, Ankole is one of the largest UK food manufacturing companies. This traditionally structured company had a very large and varied customer base, ranging from individuals to major retailers and service providers. Ankole has acquired dominance by absorbing smaller competitors. About 90 per cent of sales are on credit.

The company was marked by a surprisingly poor ability to adequately control credit:

I think economic crisis had a big part of it and I think they've realised that there's way too much risk [...] and should it go wrong or tits up (as the saying goes) we're in deep trouble, because I mean they have millions and millions of pounds just sitting there, um, not collected (Credit controller, Ankole).

Unlike Bascule, Ankole had a poorly qualified and dispersed credit control team. The numbers and range of Ankole's customers posed information asymmetry challenges in terms of tracking and monitoring large numbers of customers and the need for agile credit knowledge spanning a variety of business environments. These, together with Ankole's substantial size, produced an imperative for proactive credit control with high levels of skills and awareness. However, the company's market dominance, and the plenitude of customers, had led to complacency.

Ankole's trade credit function was in some disarray. A senior credit controller reported that he had received just two weeks of training from the firm and had yet to complete a professional qualification in credit management. The credit function was isolated from the rest of the business and was essentially used as a debt-chasing service. This made it difficult to develop requisite knowledge about the firm's business and its customers. Ankole had only recently started to help staff to develop necessary technical skills and there was, as yet, little evident opportunity to deploy these. The credit team had poor knowledge of the basic terms on which credit was given because these decisions were taken by others without the team's involvement. Ankole's large and diverse customer base obviously embodied a huge amount of data, but posed challenges in terms of its collection and processing into useful information.

The problems went beyond the fact that the credit control team did not have the requisite level of skill to know the customers and inform company strategy. The firm had grown by acquisition and many of the systems in use for tracking customers and their debts were incompatible:

You've got three different accounting systems for the business, there's not just one [...] so you've got three different types of reports, information's all different, there's nothing the same $[\ldots]$ because the depot don't see the accounts any more, it's all done in head office and you can 


\section{QRAM 11,3}

266 imagine how many hundreds of thousands there are. There's a team of [...] about four with a manager doing hundreds [...] well a hundred and eighty five thousand customers (Credit Controller, Ankole).

Sales personnel worked on a commission basis, leading to an almost blatant disregard for information sharing that led to problems with even basic credit control:

The [ledger] I've got now is so much smaller, but the accounts are held in the sites, so the only way to actually get the information is to go to the sites, so because the people in the sites aren't necessarily credit controllers [...] when something goes wrong they don't know what to do and then instead of asking they keep quiet and then [...] when the reports come through each week you just see the graph going way high and, and now I travel around literally and just deal with them (Credit controller, Ankole).

This poor communication cut both ways - the credit team were so unsure about their own policies and procedures that there is little evidence that they were able to communicate these effectively to the sales staff. Asked if the sales department decided who to extend credit to, our respondent replied:

Oh no, "we" decide, but they pick and choose who they send through on application [...] Of the 300 accounts that we have where we've not seen credit applications for them, that's sales [...] doing a dodgy [...] Sales will! They'll go out, do what they have to do. What they're meant to do is obviously get the customers, do a credit form, if they want credit, send it in to us, and before we even supply them, that has to be accepted or declined. That doesn't happen. So there's no credit agreements, it's all done on [...] goodwill [...][verbally][...] which is useless. [In] six months [my colleague] had 500 gains of business, yet only 20 applications had gone through the credit department (Credit Controller, Ankole).

Not only was there poor control of the basic data around customers, this information was not used in any strategic sense to develop the business, allowing large and powerful customers to call the shots:

The amount of discount they take's obscene. You've got settlement discount, volume discount, retention discount [...] you can get a remittance, say, it is [...] the bottom figure's $£ 70,000$. I've seen it and then at the very top you've got minus 20,40 [...] so the actual value of it is probably near $£ 130,000$, so they’ve just deducted so much money. Just because they can (Credit Controller, Ankole).

Ankole's failure to correct information asymmetries was closely related to both the poor skills and knowledge possessed by the credit team and their structural position within the firm. The credit function was decentralised, pressed for staff, a sub-division of finance, and relegated to debt collecting. Efforts to collect debt proactively were shunned by senior management, yet on occasions these approaches had proved effective:

It's debateable sometimes whether [sales] have actually done all they can. So I always ring the customer and say, "What do you want? I'll sign [the third-party collection order] now or you can work with me". Most of the time [...] they'll just say, 'I don't want the aggravation, I'll just pay', so I give them the number and they just go off and pay it, but some of them [...] a few colourful words, the phone goes down and then [...] just sign [the third party collection order] off and send it off (Credit Controller, Ankole).

Late payment decisions regarding write-offs or renegotiating contracts were ultimately resolved by the senior management - to whom the credit controllers had little or no 
direct access. There had been an obvious push in response to cash difficulties, but this was top-down rather than the result of a restructuring of the function.

\section{Creditable behaviour?}

\section{Building customer relationships}

Dikka is a large and long-established limited liability partnership providing design services on (mostly) major construction projects. The partnership basis means that senior personnel are all closely involved in building organisational value. Dikka's small customer base mostly comprises large organisations across the world. The projects have complicated, multi-partner supply chains, making customer relationships long-term, long-distance and multi-faceted - they were described by our respondent as "somewhat tortuous" to negotiate. Although all of Dikka's work is on credit, until five years ago it had no dedicated credit management function and very poor performance in this area. Since then, the company had taken a number of effective steps to address this perceived deficiency.

Our respondent, the most senior credit manager, was an Institute of Credit Management (an organisation of trade credit professionals) fellow with 25 years' experience, and nationally recognised in his professional community. He had a keen awareness of the role of the credit function:

[The customers] know and you know that actually the relationship is too valuable to be compromised, our projects last for four and five years and, if you fall out with the client then, you know, you've got a damaged relationship that you've got to work with for four or five years. So it's always the value judgement (Group credit nanager, Dikka).

Information was perceived as a key element in building these relationships:

My team build up that intelligence from that sort of collection route [...] and they get to know the key people in that. I'm very keen that they develop relationships with those customers (Group credit manager, Dikka).

Awareness of the credit management team's ability to build customer relationships were formally communicated to the rest of the company via a comprehensive credit policy, introduced and implemented by the credit manager. This policy was endorsed by senior management and integrated into the corporate governance structure.

The skills of the credit team are evidenced by the way in which this policy was not a one-way process. Given the complexity and nature of the contracts, it was:

$[\ldots]$ quite difficult to apply a blanket policy [...] you need to know how to adapt it to specific circumstances, this needs skills, experience and awareness of what goes on in your company and in your sector (Group credit manager, Dikka).

This credit manager prided himself on working well with other functional areas in the firm. It had taken time and effort to reach this position, and he had been forced to work slowly to achieve a change in organisational ethos. Consequently, credit management was proactively embedded in the firm and the group credit manager was a board member. Dikka has no sales department as such - the "salesmen are the partners in the firm, the senior directors [...] spend a lot of time building relationships with their client". In this partnership, the classic tension that can develop between sales and credit management did not emerge - those intent on procuring and retaining customers were also mindful of the profit imperative. Credit management was accorded a respectful position in the organisation: 


\section{QRAM 11,3}

We're not going to destroy your [the partners'] relationship with your clients, what we are going to do is enhance them and how? We're going to enhance them by giving you X, Y, Z. Most of these guys are actually really grateful that they're getting better intelligence on the clients that they're going to be dealing with (Group Credit Manager, Dikka).

The group credit manager was closely integrated into decision-making, providing intelligence and strategic direction. He differentiated those clients that genuinely need some leeway due to short-term issues and those that have:

[...] obviously taken the commercial decision that actually we can improve our treasury position by not paying people and if we've got to pay a few court fees, well that's what we've got to do. [One major customer was] absolutely unscrupulous. They called together all of their consultants, said, "We need you to drop your fees by 40 per cent" [...] there was a stunned silence round the room and people asked, "Well do you expect a 40 per cent reduction in service then?", "No, no, we expect you to do the same job. We believe that our position is such that we can ask for this reduction and if you don't want to do it then there'll be somebody else out there who does". We wrote back to them and said, "We can't do 40 per cent, we can give you x\% reduction, but you won't get this that and the other AND you have to guarantee to pay to terms" and they accepted (Group Credit Manager, Dikka).

Awareness, experience of dealing with such large client, and the organisational status of this credit management team allowed it to take a key role in such a risky decision.

Manzetti is a well-established large public company providing services to a very diverse customer base ranging from multinationals to individuals. With the exception of a few very large business customers, the size of the customer base precluded close customer relationships and generated a high degree of separation between sales and credit management. A large number of customer-facing functions, including some credit management ones, were outsourced, often internationally.

Consequently, Manzetti operated back-office debt collection rather than proactive credit management - it had a "Billing Director" rather than a credit manager. Whereas in Dikka the credit workers were closely involved in building relationships with customers, in Manzetti they were debt collectors; their only contact with customers was when pursuing payment.

The skills and aptitudes of the credit workers were largely appropriate only to this limited work. Debt monitoring and collection is highly automated. Consequently, there are few staff, and with few skills, in the credit area.

The company does no risk analysis of customers or in-depth reports of defaulters:

There are lot of customers and it makes it difficult from a credit management point of view to be personal with those customers and build a good relationship. It's more reliant on systems and technology to help you with the collections really [...] moving into more of a sort of IT managing solutions and complex networks (Billing/Business Enterprise Team leader, Manzetti).

Nor did the credit department collect and collate information on customers, even poor-payers:

There's not really systems in place to warn you of these potential wrong-doers or potential customers that are going out of business other than the press watch which is not always that reliable. (Billing/Business Enterprise Team leader, Manzetti).

The credit team were not able to provide detailed information on customer behaviour:

Due to the volumes it's so hard to keep track of the customers but we will have system generated ratings as such [...] You'll see the invoices and when they paid and you can just 
build up a picture, but I don't think as a whole [...] I don't think there's really a dedicated team anywhere who will keep track (Billing/Business Enterprise Team leader, Manzetti).

Manzetti confused customer service and debt collection, putting strain on credit management:

So if you ring up and say, "I'm from credit management", it sounds a bit debt collector-ish! The customer's going to be a little bit, 'Hang on, so they're after the money rather than [...] I've had all these issues, aren't you going to help me resolve them?', rather than ask for money (Billing/ Business Enterprise Team leader, Manzetti).

The company uses third-party agents to deal with bad debts, denying itself the opportunity for direct customer contact:

The debt collection agency makes an absolute fortune, a killing, off us because [...] I don't think it's so much a failing of our credit management process. It might be because we've got too many customers and not enough credit managers and maybe not a robust enough billing system (Billing/Business Enterprise Team leader, Manzetti).

Manzetti, with its extensive customer base, has not systematised its credit management operations. There was also a feeling that the credit function was, quite simply, understaffed. Communications between the credit teams and other significant departments, such as sales, were poor. Until quite recently, the sales workers had been on a commission basis and evidenced little concern if a customer was a bad payer:

There are actually commission corporate clawbacks now, so if a customer doesn't pay their bill for whatever reason [the sale staff] lose their commission, so it has a flip side to it because yes it's great because the sales manager is like an extra credit controller and they have the best contact with the customer and the best relationship, but they are then the bane of your life because they'll ring you up [complaining that they can't buy their kids Christmas presents] (Billing/Business Enterprise Team leader, Manzetti).

Communications with customers fared little better. Many activities in the company are outsourced, so customers rarely deal with the same person. Third-party sales agents tended to concentrate on sales maximisation, regardless of the customer creditworthiness. Smaller customers were left to the automated debt recovery systems whilst the debt workers call:

[...] the bigger clients who we need to really ring and pester for money rather than the ones who just won't pay and you let the system take care of them so to speak and the call centres. The bigger clients will obviously get the calls, the personal touch, the human element of collections and it's the most effective way, but there're not enough people and there're too many customers. Even the big clients, sometimes you have to rely on the automation (Billing/Business Enterprise Team leader, Manzetti).

As a result, the company suffers badly from bad debts, with the:

$[\ldots]$ budget for a monthly write-off, it's rarely ever understated [...] the volumes of bad debt and the write-offs that go through on a monthly basis is always over-budget or just not put through that month because it simply is over the agreed limit of what can be written off (Billing/Business Enterprise Team leader, Manzetti).

The absence of contact with customers meant that the credit team did not have detailed or useful organised information on most customers. This meant that there was little information shared with credit decision-makers: 


\section{QRAM 11,3}

270
If I'm honest I don't think we utilise it [information] enough, because of the sheer volume of customers $[\ldots]$ we try and communicate with the sales staff as much as possible, but there's not enough communication between the two, but in terms of the overall trends due to the volumes it's so hard to keep track of the customers (Billing/Business Enterprise Team leader, Manzetti).

Poor organisational positioning, where credit staff worked under pressure to get the initial bills right to enhance customer service, but, at the same time, were mainly involved with back-end collecting activities, created tensions. Increasing competition for customers was matched by an inability to deal with specific consumer issues. In the past, for instance, the credit team used to work out payment plans for customers struggling to pay. However, the automation, twinned with the recession, means that these plans are almost impossible:

[... . to get authorised and now they're under a lot more scrutiny from senior management, they'llalways ask us to get as much upfront as possible and it's tricky to negotiate with customers when you know there's a genuine case, it's definitely tricky (Billing/Business Enterprise Team leader, Manzetti).

So even if the credit team wanted to use its initiative to help customers, it had little ability to influence decisions. Moreover, their knowledge and awareness was lost in the largely automated services.

\section{Costs of finance}

Redemptores is a large, well-established company supplying products/services based around the basic construction commodities that it produces. Involved with some very large projects, it is one of the market leaders and sells to low credit-risk customers. Most transactions are on credit. A conventionally structured, market-leading firm, Redemptores uses its efficient trade credit management operation to successfully mitigate the cost of granting credit.

The highly skilled and qualified senior credit manager explained that, as well as the need for skill and awareness, business acumen played an important role in reducing costs:

If you can secure major volumes of [products], then it's sometimes worth giving away long credit [...] but prior to doing that you work out what the impact on your performance, cash-flow, risk [...] will it impact on bad debt provision? [...] We're there to be the policemen of the risk versus return (senior credit manager, Redemptores).

Much skill was deployed in negotiating and determining credit terms, prices, etc. A complex cost-benefit analysis tool included a "nine-box matrix", with parameters such as credit cost vs volume, risk vs return, length vs price, limit vs risk, etc. However, such calculations merely informed very competent staff who had the discretion to make decisions based on experience and company knowledge. There was a keen awareness of market conditions and how to successfully exploit these:

Somebody once accused me and said, "You're just using your power in the market" and I said, "Are you expecting me to actually apologise for that? I'm powerful, but that is part and parcel of capitalism"(Senior credit manager, Redemptores).

Given its powerful market position, Redemptores only entered contracts on the basis of a reasonably assured financial return - customer relationship building was not a key priority, but the company was committed to using credit to increase profitability. Redemptores demanded financial reciprocity from major customers. One customer wanted 60-days credit:

[...] but we are receiving in reciprocation a guaranteed set of prices which gives us good profit and in addition to that, we are receiving guaranteed volumes. So we've offset the two things, there's 
benefit for us [...] We will not hand out additional terms without something in reciprocation (Senior credit manager, Redemptores).

The credit department's mission was communicated throughout the firm and specific credit information was shared via a weekly report. The senior credit manager described how the credit policy has board approval and was "part of the strategic decision-making" - he reported directly and regularly to the board on credit costs. The credit team was a principal intermediary between customers and the rest of the firm, educating customers about Redemptores' requirements of them. They imposed a strict and proactive regime. Forward intelligence on customers' creditworthiness and payment behaviour enabled them to concentrate on those most likely to delay payment, thereby reducing the cost of chasing. Systems for customer communication had significantly reduced credit costs. An electronic customer portal gave clients access to sophisticated account information, reducing queries that are often the source of late payment.

As a result of excellent credit information, the team was able to keep daily close control of credit costs. Tight control of the net credit position meant that credit from Redemptores' suppliers funded the cost of extending credit to customers. This involved an aggressive stance, enabled by its dominant market position:

Yes, and we force other people to pay [...] we pay them late, we have to protect our cash position, pure and simple (Senior Credit Manager, Redemptores).

Structurally, the credit team is clearly an integral part of Redemptores modus operandi. The head of the credit team is a board member and the team's actions permeate and control all aspects of business decision making.

Brolga is a medium-sized company manufacturing and distributing capital equipment for the built environment. It was experiencing financial difficulties, and many activities have been outsourced and staff numbers reduced. Brolga's customer base was very concentrated, with some 45 per cent of business derived from 2 per cent of customers. A main objective of the firm was to expand its market share, which resulted in the company over-extending itself. As a consequence, the cost of credit extended to customers escalated, as did costs associated with late payment and default.

Six years ago the company did not have a credit team - decision-making was on a largely ad hoc basis, resulting in a very poor trade credit position. The recently established credit team had some members with evident skills and/or experience, but it was not part of the credit decision-making. The credit manager said: "we have the knowhow to reduce credit costs, improve our cash-flow forecast by better risk mitigation, but it's all sales [team] driven". The sales team were extending generous credit terms to attract customers, the costs of which were not offset by sales/customer base growth.

Despite this poor position, Brolga had cut staff in the credit section from 16 to 6 . Yet, the company has a wide customer base, which generated many disputes that consumed the time of credit staff and drew their efforts away from more strategic work. The skills and capacities of the team were not widely recognised within Brolga and they were resented as the "sales prevention" department. Consequently, the credit staff were not motivated to develop their skills further:

I would love someone to come knocking on door saying, "Please support me to my Institute [of Credit Management] exams". I'd love someone to say, "I'd want your job in five/six years time". I've got nothing like that (Credit manager, Brolga). 


\section{QRAM 11,3}

272
There was very poor communication of information between the credit team, the sales and the rest of the company:

[Often] the first thing you knew about an order was when basically the lorry was ready to take the piece of machinery away and then suddenly it's [...] there's an issue from a credit side (Credit manager, Brolga).

The credit policy is not used and had not been updated since 2007. The credit team did gather information on key customers, but they were not the decision-makers or the negotiators, and although they shared this information with co-workers, nobody seemed to use it. Consequently, no real analysis of late payment was performed - "It is certainly something that we should be doing more to understand what is actually happening, but we don't" (credit manager, Brolga). The credit team had limited power to use the information that they collected from continual late payers, especially larger customers. "There's the fear factor, "well they won't buy from us again". Do we want people to buy from us who don't pay? If they don't, then there is a cost" (Credit manager, Brolga).

The credit team felt that an issue here was that the sales staff were driven by a bonus culture and suffered no adverse consequences for taking risky and costly credit decisions:

We have a sales manager coming telling us that he didn't know what credit limit his customers had got, "Well, you didn't want the information when offered" [...] you can lead a horse to water, but you can't make it drink (Credit manager, Brolga)

The credit manager noted that, as the credit team has little power and no direct contact with customers, it is "very much further down [...] we get involved when [we] approve the orders, but the problem would be the negotiation would have taken place by then". For instance, the credit policy sets out clearly the credit limits and how orders should be processed:

$[\ldots]$ but the problem is a customer doesn't know what that credit limit is and therefore how can we expect them to follow [...] to play the game if they don't know what the rules of the game are? So the terms and conditions are not communicated to the customers (Credit manager, Brolga).

The absence of a clear strategy for sales growth in the firm meant that "it sold to anybody who comes knocking on its door" (Credit manager, Brolga). Consequently, the credit team deals mainly with collection, disputed invoices and late payment. Brolga's credit manager described himself as "basically in charge of the collection team". This increased the cost of granting credit; in contrast to Redemptores, Brolga's passive credit management was not optimised to reduce costs.

Many of Brolga's customers had no working capital facility so they "purely use trade finance" and the credit team had no power to stop this - "why didn't [the customer] pay to terms? I didn't ask, we know it's a systemic issue” (credit manager, Brolga). Customers paid at their convenience without any penalty as the credit team had no power to charge interest, put customers on stop, or even use any collection techniques to actively chase them:

You've got a big company that paid late, you charge them late payment interest and they don't pay it, what do you do? Well, you're just being busy fools creating more costs and then you have to write it off to interest (Credit manager, Brolga).

It's breaking this culture that is difficult because I appreciate that it's a sales driven business. However, nowhere does it say in our policy that we expect customers to continually pay us late[...] everybody has the occasion when they pay late, that's OK, but if it's continually paying late then there has to be a consequence for the customer's actions, but we don't (Credit Manager, Brolga). 
In Brolga, because trade credit was seen as a simple debt collection function, it was not used to generate cost advantage. The credit manager dealt mainly with dispute resolution, late payment collection and writing off bad debts. He was neither highly enough placed in the hierarchy to get the best value out of the trade credit operation nor well placed to negotiate credit terms and conditions with customers.

\section{Concluding discussion}

Until relatively recently, trade credit management has been something of a Cinderella

subject - the subject of some normative academic research but often largely relegated to a back-office technical function in firms (Paul and Boden, 2008). The current economic crisis provides an imperative for firms to pay new attention to this area if they are achieve the significant competitive advantages promised by the academic literature: the mitigation of information asymmetries, the building and sustaining of customer relationships and the reduction of financing costs.

To date, very little work has been undertaken on the actuality of firms' management of trade credit, giving consideration to how they might shape and organise themselves effectively. Treated as a technical function, trade credit management is simply a set of techniques and processes. However, the evidence indicates that, when relegated to this role, trade credit fails to deliver promised possibilities. Rather, good trade credit management has a set of essential relational attributes that cannot be explored or tested using the positivist approaches of much mainstream trade credit research.

Ours is the first substantial in-depth qualitative study of how trade credit is actually managed within the firm at the relational level. The data allow exploration of the reasons why firms might or might not realise the strategic advantages of trade credit identified in the academic literature. We found three firm organisational attributes that affect firms' credit management practises: the level of the credit team's skills and awareness, communication of credit information and the structural position of the activity in the firm. These attributes provide appropriate analytical lenses through which the relational nature of firms' trade credit work can be explored.

This paper offers a rich set of contrasting stories of firms that exhibited extremely heterogeneous arrangements with regard to their trade credit management. The successful firms had successfully adapted to their circumstances and were proactive in their engagement. Skills, communication and structural position within the firm are obviously significantly interlinked and, in these firms, these factors came together effectively.

We found that in companies where trade credit was performed by skilled credit teams aware of their importance and who communicated credit information to others across the organisation from the vantage point of an appropriate structural position took a more strategic approach to trade credit management and realised many of the benefits. For instance, we found that firms offering good quality products/services did not offer longer (than required) credit terms and did not allow customers to pay beyond due dates without penalty. In addition, those who assessed customers' risk before the sales had less late payment and default problems. Thus efficient trade credit management cut firms' credit costs.

Very noticeably, the structural position of the credit function was highly significant. In cases where the function was appropriately positioned within the firm and the staff had sufficient influence, trade credit was used strategically to obtain competitive advantage. 


\section{QRAM 11,3}

274
In contrast, firms where the dominant culture was one where credit management was equated with "sales prevention" did not invest in credit staff, who, in turn, did not exhibit a clear and skilled commitment to their work, seeing themselves only as back-end debt collectors. These credit teams were often structurally isolated from key decision-makers and had poor lines of communication. The result was, in many instances, a palpable failure to achieve even basic business efficiencies.

We can identify no single framework to determine exactly how trade credit management should be practiced within firms. To a significant extent, this depends on the individuals circumstances that pertain. Rather, this work highlights the importance of three general organisational attributes and stresses the importance of making these appropriate to the context of the individual firm.

This conclusion should not be startling. However, in the UK and elsewhere, trade credit continues to be a vexing problem with frequently poor control and a failure to realise the strategic competitive advantages that can accrue. It may be that largely quantitative academic research, which has rationalised trade credit as a set of narrow functional processes, leads to proposed solutions that are simply more of the same - for instance, in the UK, government has sought to deal with the issue by the introduction of statutory interest provisions (Paul and Boden, 2011). This work therefore offers the prospect of a somewhat different conceptualisation of trade credit management as a relational aspect of a firm's control, deserving of thoughtful and nuanced solutions.

\section{References}

Lee, Y.W. and Stowe, J.D. (1993), "Product risk, asymmetric information and trade credit", Lournal of Financial and Quantitative Analvsis, Vol. 28 No. 2, pp. 285-300.

Long, M.S., Malitz, I.B. and Ravid, S.A. (1993), "Trade credit, quality guarantees and product marketability”, Financial Management, Vol. 22 No. 4, pp. 117-127.

Mian, S.L. and Smith, C.W. Jr (1992), "Accounts receivable management policy: theory and evidence", Lournal of Finance, Vol. 47 No. 1, pp. 169-200.

Ng, C.K., Smith, J.K. and Smith, R.L. (1999), "Evidence on the determinants of credit terms used in interfirm trade", Lournal of Finance, Vol. 54 No. 3, pp. 1109-1129.

Paul, S.Y. (2010), Strategic Trade Credit: An Empirical Study, VDM Publishing House Ltd, Germany, ISBN- 978-3-639-22972-1.

Paul, S.Y. and Boden, R. (2008), “The secret life of UK trade credit supply: setting a new research agenda", The British Accounting Review, Vol. 40 No. 3, pp. 272-281.

Paul, S.Y. and Boden, R. (2011), "Size matters: the late payment problem", Journal of Small Business and Enterprise Development, Vol. 18 No. 4, pp. 732-747.

Paul, S.Y. and Boden, R. (2012), "Getting paid: lessons for and from SMEs", The Association of Chartered Certified Accounts, London, March.

Paul, S.Y. and Wilson, N. (2006), "Trade credit supply: an empirical investigation of companies level data", Journal of Accounting Business and Management, Vol. 13, pp. 85-113.

Peel, M.J., Wilson, N. and Howorth, C. (2000), "Late payment and credit management in the small firm sector: empirical evidence”, International Small Business Iournal, Vol. 18 No. 2, pp. 17-37.

Petersen, M.A. and Rajan, R.G. (1997), “Trade credit: theories and evidence”, Review of Financial Studies, Vol. 10 No. 3, pp. 661-691. 
Pike, R.H. and Cheng, N.S. (2001), “Credit management: an examination of policy choices, practices and late payment in UK companies", Lournal of Business Finance and Accounting, Vol. 28 Nos 7/8, pp. 1013-1042.

Pike, R., Cheng, S., Craven, K. and Lamminaki, D. (2005), "Trade credit terms: asymmetric information and price discrimination: evidence from three continents", Journal of Business Finance and Accounting, Vol. 32 Nos 5/6, pp. 1197-1236.

Schwartz, R.A. (1974), "An economic model of trade credit", Lournal of Finance and Quantitative Analvsis, Vol. 9 No. 4, pp. 643-657.

Smith, J.K. (1987), “Trade credit and information asymmetry”, Journal of Finance, Vol. 62 No. 4, pp. 863-872.

Wilson, N. (2008), An Investigation into Payment Trends and Behaviour in the UK: 1997-2007, Credit Management Research Centre, Leeds University Business School, Leeds.

Wilson, N. and Summers, B. (2002), "Trade credit terms offered by small firms: survey evidence and empirical analysis", Journal of Business Finance and Accounting, Vol. 29 Nos 3/4, pp. 317-351.

\section{Appendix}

\begin{tabular}{lccrr}
\hline Size (by number of employees) & Number of companies & \% of companies & Cumulative \% & \\
\cline { 1 - 3 } Micro $(<10)$ & 5 & 12.50 & 12.50 & \\
Small $(10-49)$ & 4 & 10.00 & 22.00 & Table AI. \\
Medium (50-249) & 6 & 15.00 & 37.50 & Respondent group by firm \\
Large $(>249)$ & 25 & 62.50 & 100.00 & size \\
Total & 40 & 100.00 & 100.00 & \\
\hline
\end{tabular}

\begin{tabular}{|c|c|c|c|}
\hline Sectors & Number of companies & $\%$ of companies & \\
\hline Services & 10 & 25.00 & \\
\hline Construction/building/engineering & 13 & 32.50 & \\
\hline IT/software & 8 & 20.00 & \\
\hline Food/drink distribution & 4 & 10.00 & \\
\hline $\begin{array}{l}\text { Others (publishing, electronics, promotional } \\
\text { goods, manufacturing/distribution) }\end{array}$ & 5 & 12.50 & $\begin{array}{l}\text { Table AII. } \\
\text { Respondent group by }\end{array}$ \\
\hline Total & 40 & 100.00 & sector \\
\hline
\end{tabular}

\footnotetext{
About the authors

Rebecca Boden, $\mathrm{PhD}$, is a Professor of Critical Management at the University of Roehampton Business School, London. Rebecca Boden is the corresponding author and can be contacted at: Rebecca.boden@roehampton.ac.uk

Salima Yassia Paul, PhD, is a Professor of Credit Management at the School of Management, University of Plymouth.
}

To purchase reprints of this article please e-mail: reprints@emeraldinsight.com Or visit our web site for further details: www.emeraldinsight.com/reprints 